\title{
POTOMETRIUM (Pot Tanaman Geometris dan Terarium) serta Pemasaran Digital Bagi Kelompok Penjual Tanaman Hias di Kelurahan Maccini Sombala, Kota Makassar
}

\section{POTOMETRIUM (Geometric and Terraium Pot Plants) and Digital Marketing for The Ornamental Plant Traders Group in Maccini Sombala Village, Makassar City}

\author{
${ }^{1}$ Citra Amalia Amal, ${ }^{1}$ Andi Annisa Amalia, ${ }^{2}$ Sri Andayaningsih \\ ${ }^{1}$ Program Studi Arsitektur, Fakultas Teknik, Universitas Muhammadiyah, Makassar \\ 2 Program Studi Manajemen, Fakultas Ekonomi dan Bisnis, Universitas Muhammadiyah, \\ Makassar
}

Korespondensi: C. Amalia, citraamaliaamal@unismuh.ac.id

\begin{abstract}
The world of architecture is currently colored by the development of farming methods for urbanites in limited land by arranging plants into special containers of high artistic value such as terrariums and pots in the style of industrial geometry. Some of the problems faced by ornamental plant sellers are the high competition in selling similar types of potted plants because the types of pots sold are generally the same as those on the market, not yet skilled in assembling cactus and succulent plants into terrarium containers, and the sales system is still conventional in nature. To overcome these problems, community service was carried out in the form of developing productive partners with the theme POTOMETRIUM (Geometry and Terrarium Plant Pots). POTMETRIUM PPM activities consist of preparatory activities, identification and classification of ornamental plant sales groups, dissemination of POTOMETRIUM product knowledge and socialization of PKM implementation activities, implementation of geometric pot making workshops, implementation of technical terrarium arranging workshops, implementation of digital marketing technical workshops, making video tutorials POTOMETRIUM, publications implementation of activities, preparation of activity reports, and implementation of monitoring and evaluation of the results of PKM activities.
\end{abstract}

Keywords: Geometric, terrarium, product, digital, ornamental plant. 
terarium, pelaksanaan workshop teknis pemasaran digital, pembuatan video tutorial POTOMETRIUM, publikasi pelaksanaan kegiatan, penyusunan laporan kegiatan, dan pelaksanaan monitoring serta evaluasi hasil kegiatan PKM.

Kata Kunci: Geometris, terarium, produk, digital marketing, tanaman hias.

\section{Pendahuluan}

CV. Ary Gasebo selaku mitra Program Kemitraan Masyarakat (PKM) adalah sebuah perusahaan yang didirikan oleh Bapak Andi Aryanto pada tahun 2007, yang bergerak di bidang penjualan tanaman hias. Hingga saat ini, mitra PKM telah memiliki tiga cabang penjualan tanaman yaitu cabang yang menjual tanaman besar setinggi 3-7 meter, tanaman di luar ruangan (outdoor), dan tanaman dalam ruangan (indoor) serta tanaman buah. Dengan mengusung konsep one stop solution dalam menjalankan perusahaannya, mitra PKM menyediakan beragam jenis tanaman, variasi alat bercocok tanam, hingga jasa desain taman, pembuatan taman, perawatan taman, penyewaan tanaman, dekorasi taman panggung serta pembuatan gazebo.

Dunia arsitektur saat ini diwarnai dengan perkembangan terarium sebagai salah satu elemen interior pada rumah tinggal, kantor, butik, kafe, hotel, maupun bangunan komersial lainnya. Akan tetapi, tim pengusul menilai jenis pot tanaman yang dipasarkan oleh mitra PKM belum mengikuti perkembangan tren arsitektur dan interior, serta masih terbatas menjual kembali pot tanaman yang diproduksi secara massal hingga tidak memiliki keunikan dan mudah ditemukan di berbagai pesaing usaha penjualan alat pertamanan lainnya. Permasalahan ini diakibatkan kurangnya pengetahuan mengenai perkembangan tren arsitektur dan interior saat ini dengan tema industrial dan bentuk-bentuk geometris, disamping keterampilan SDM dalam memproduksi pot tanaman. Pot tanaman dengan bentuk geometris memberi kesan unik, modern, dinamis, dan aplikatif di ruang formal maupun non formal. Bahan yang digunakan untuk membuat pot tanaman geometris cukup mudah ditemukan, serta cara pembuatannya tidak rumit. Sehingga, memungkinkan bagi mitra PKM untuk memproduksi sendiri pot tanaman yang akan dipasarkannya.

Selain itu, tim pengusul juga melihat adanya peluang bagi mitra untuk memproduksi dan memasarkan produk terarium di Kota Makassar. Apalagi, tanaman kaktus dan sukulen sebagai bahan utama pembuatan terarium bukanlah tanaman yang asing bagi mitra PKM, disamping masih kurangnya penjual terarium di Kota Makassar khususnya di sepanjang Danau Tanjung Bunga Kelurahan Maccini Sombala Kecamatan Tamalate Kota Makassar. Sayangnya, pengetahuan serta Sumber Daya Manusia (SDM) yang terampil menata tanaman ke dalam terarium belum dimiliki oleh mitra PKM. Bertanam terarium ini menjadi solusi yang murah dan mudah untuk mengantisipasi radiasi secara sederhana, penanamannya juga tidak memakan lahan yang besar, perawatannya pun mudah dan hemat air (Charina, dkk., 2012).

Pembeli yang berbelanja di mitra PKM adalah terbatas pada masyarakat Kota Makassar dan sekitarnya. Tentunya cukup disayangkan mengingat perkembangan teknologi saat ini sangat memungkinkan pembeli bukan hanya masyarakat dari Kota Makassar saja. Salah satu metode pemasaran yang efektif dapat dilakukan mitra adalah pemasaran digital, apalagi di era milenial saat ini pembeli lebih cenderung senang berbelanja secara online. Menurut Utami \& Firdaus (2018), keberadaan dan penggunaan internet memberikan konsukuensi tidak hanya pada perubahan gaya hidup modern namun juga mengubah perilaku individu dalam melakukan aktivitas pembelian produk dan/atau jasa secara daring (online), bauran pemasaran secara stimultan memberikan pengaruh terhadap penciptaan keputusan pembelian yang menggiring konsumen melakukan pembelian. Untuk 
itu, maka sistem pemasaran konvensional yang selama ini dilakukan mitra dapat dikembangkan ke sistem pemasaran digital.

Penerapan teknik budidaya tanaman dapat meningkatkan perekonomian rumah tangga, mempertahankan kesehatan keluarga, adanya alih teknologi, serta meningkatkan pengetahuan, keterampilan dan ketertarikan kelompok untuk mencoba melakukan hal baru (Dewi \& Widiyawati, 2019). Melalui kegiatan pengabdian POTOMETRIUM ini, diharapkan dapat menjadi value added (nilai tambah) bagi Kelompok Penjual Tanaman Hias dalam teknik budidaya tanaman dan adanya diferensiasi (pembeda) dengan teknik budidaya yang umumnya mereka lakukan sebelumnya, melakukan sistem pemasaran online, serta anggota kelompok dapat berwirausaha mandiri.

\section{Metode Pelaksanaan}

Tempat dan Waktu. Kegiatan PPM POTOMETRIUM berupa sosialisai kegiatan, workshop pembuatan pot geometris, dan workshop digital marketing dilaksanakan di Galeri Penjualan Tanaman Hias CV Ary Gazebo Kelurahan Maccini Sombala Kecamatan Tamalate (Gambar 1). Sedangkan kegiatan berupa workshop merangkai terarium dan workshop pembuatan website dilaksanakan di Warung Upnormal Jalan Andi Djemma Kelurahan Mamajang Dalam Kecamaatan Mamajang Kota Makassar. Waktu pelaksanaan pada Bulan Mei hingga Bulan September 2019.

Khalayak Sasaran. Kegiatan PPM POTOMETRIUM dilakukan pada kelompok penjual tanaman hias yang ada di Kelurahan Maccini Sombala. Jumlah peserta yang mengikuti rangkaian kegiatan workshop rata-rata adalah 30 orang terdiri dari kelompok perempuan dan kelompok laki-laki.
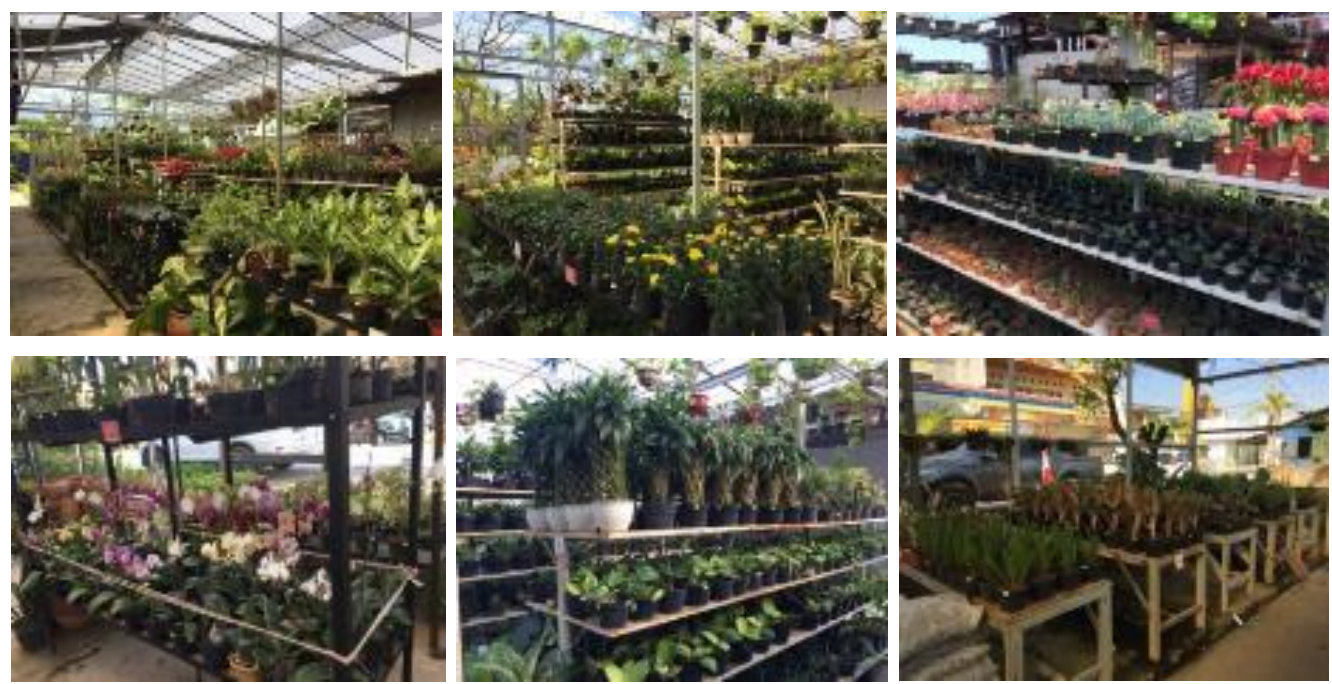

Gambar 1. Berbagai Jenis Tanaman di CV. Ary Gasebo

Metode Pengabdian. Metode pelaksanaan kegiatan adalah metode workshop berdasarkan aspek permasalahan produksi, keterbatasan keterampilan dan pemasaran. Aspek produksi dan keterbatasan keterampilan dalam membuat pot, maka dilakukan workshop I pembuatan pot geometris dimana peserta melalukan penentuan desain, praktik merangkai bahan dan membuat standing pot dengan beberapa jenis menggunakan teknik pengelasan. Aspek produksi dan keterbatasan keterampilan dalam merangkai terarium maka dilakukan workshop II merangkai terarium dimana peserta menentukan tema, praktik pembuatan terarium dengan sistem layer, pemilihan jenis kaktus dan sukulen, pemilihan wadah dan teknik perawatan terarium. Aspek pemasaran dilakukan worskhop pembuatan website dengan mengajarkan pengoperasian website meliputi cara berbelanja online, setting 
konfigurasi dan kategori, menambahkan barang. Selain itu, penguatan terhadap aspek pemasaran, dilakukan pula workshop digital marketing dimana peserta mengenal teknik digital marketing, konsep dasar media sosial dan menghasilkan prospek pemasaran dari media sosial. Media sosial merupakan tools marketing yang bisa dikatakan cukup efektif untuk membantu strategi pemasaran (Dewi \& Widiyawati, 2019).

Indikator Keberhasilan. Indikator keberhasilan dari kegiatan PPM POTOMETRIUM adalah penjual tanaman hias telah mampu membuat pot geometris, terampil merangkai sukulen dan kaktus ke dalam wadah terarium yang bernilai estetika, peserta yang dulunya hanya sebagai karyawan dapat berinisiatif membuka usaha sendiri, pemasaran produk POTOMETRIUM dapat dilakukan secara online dan pihak mitra mampu memproduksi pot geometris dan terarium sebagai salah satu inovasi produk penjualan tanaman di galeri penjualan tanaman hias yang ada di Maccini Sombala.

Metode Evaluasi. Bentuk evaluasi akan dilakukan pada produk POTOMETRIUM terutama dalam pemilihan jenis tanaman, media tanam, pembasmian hama, seni menanam, motif dekorasi wadah dan tema, serta kemudahan dalam pemeliharaan produk tanaman yang akan dipasarkan. Evaluasi juga dilakukan terhadap website POTOMETRIUM mengenai kemampuan mitra dalam mengoperasikan website terutama dalam menambahkan produk jualan. Selain itu, dilakukan juga evaluasi terhadap jenis produk yang akan didisplay oleh pihak mitra pada galeri penjualan dan tingkat minat konsumen terhadap produk pot geometri dan terarium.

\section{Hasil dan Pembahasan}

\section{A. Persiapan dan Identifikasi Mitra Kegiatan PPM}

Tahap persiapan kegiatan PKM meliputi identifikasi kelompok yang akan menjadi khalayak sasaran, perumusan konsep pengabdian masyarakat, jenis produk yang akan dikembangkan dan mitra sasaran serta penyusunan proposal PKM. Setelah tahap persiapan dilakukan, maka langkah selanjutnya adalah mengidentifikasi kelompok mitra Penjual Tanaman Hias yang menjadi sasaran. Beberapa hal yang diidentifikasi diantaranya melihat profil mitra PKM, jumlah anggota kelompok, jenis kegiatan kelompok yang rutin dilakukan, jenis tanaman yang dominan dijual mitra, klasifikasi kelompok mitra, orientasi kelompok dan sasaran pemasaran, dan penyepakatan jadwal dan metode pelaksanan pengabdian.

\section{B. Sosialisasi}

Sosialisasi kegiatan PPM POTOMETRIUM dilaksanakan di Galeri Penjualan Tanaman Hias Milik Pihak Mitra CV. Ary Gazebo pada Bulan Mei Tahun 2019. Kegiatan ini bertujuan untuk memperkenalkan produk POTOTMETRIUM yang akan diabdikan kepada mitra, tahapan pelaksanaan workshop dan target luaran yang akan dicapai.

\section{Workshop Pembuatan Pot Geometris}

Workshop pertama adalah pembuatan pot geomegtris dilaksanakan di Galeri Penjualan Tanaman Hias Milik Pihak Mitra CV. Ary Gazebo pada Bulan Juni hingga Juli Tahun 2019. Kegiatannya adalah melatih penjual tanaman untuk membuat standing pot rendah, standing pot tinggi dan pot geometri yang dapat digantung di dinding dengan menggunakan tema industrial. Bahan utama yang digunakan adalah pot, papan palet ukuran $12 \times 40 \times 1,5 \mathrm{~cm}$, besi beton diameter 8 finishing cat dico hitam dan putih, rangka besi strip, dan besi hollow ukuran $2 \times 2$. Teknik yang digunakan adalah teknik pengelasan. Rangkaian Kegiatan wokrshop mencakup pengenalan alat dan bahan, penentuan desain standing pot rendah, standing pot tinggi dan pot gantung dinding, pengukuran dan pemotongan bahan, perangkaian bahan (teknik las), penghalusan rangkaian pot (teknik dempul), pengecatan dan finishing (Gambar 2 dan 3). 

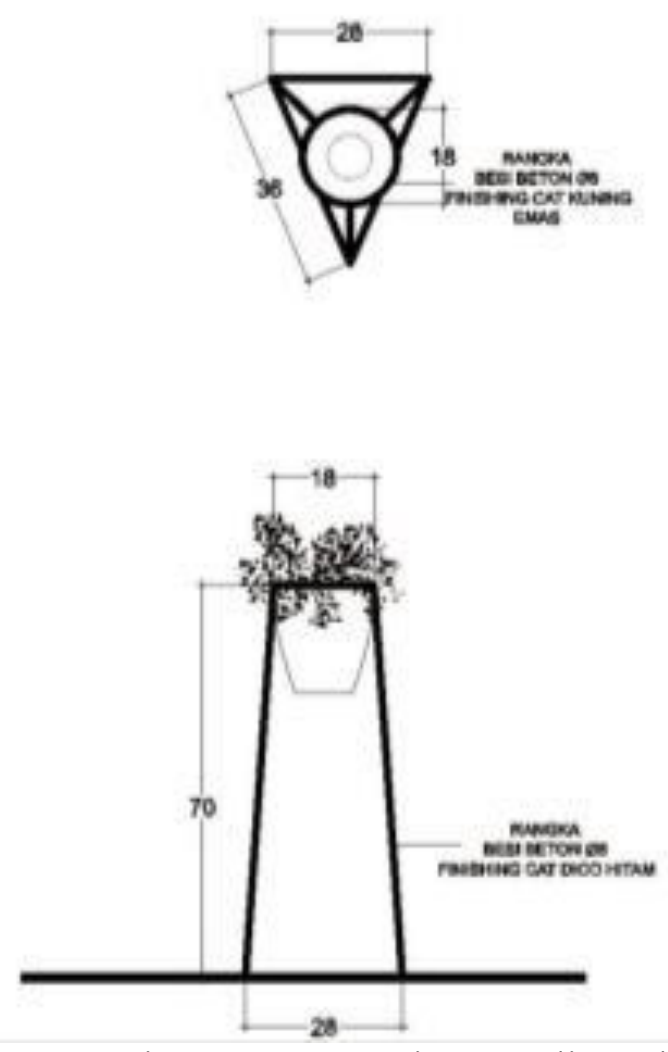

Gambar 2. Desain pot geometris standing planter tinggi
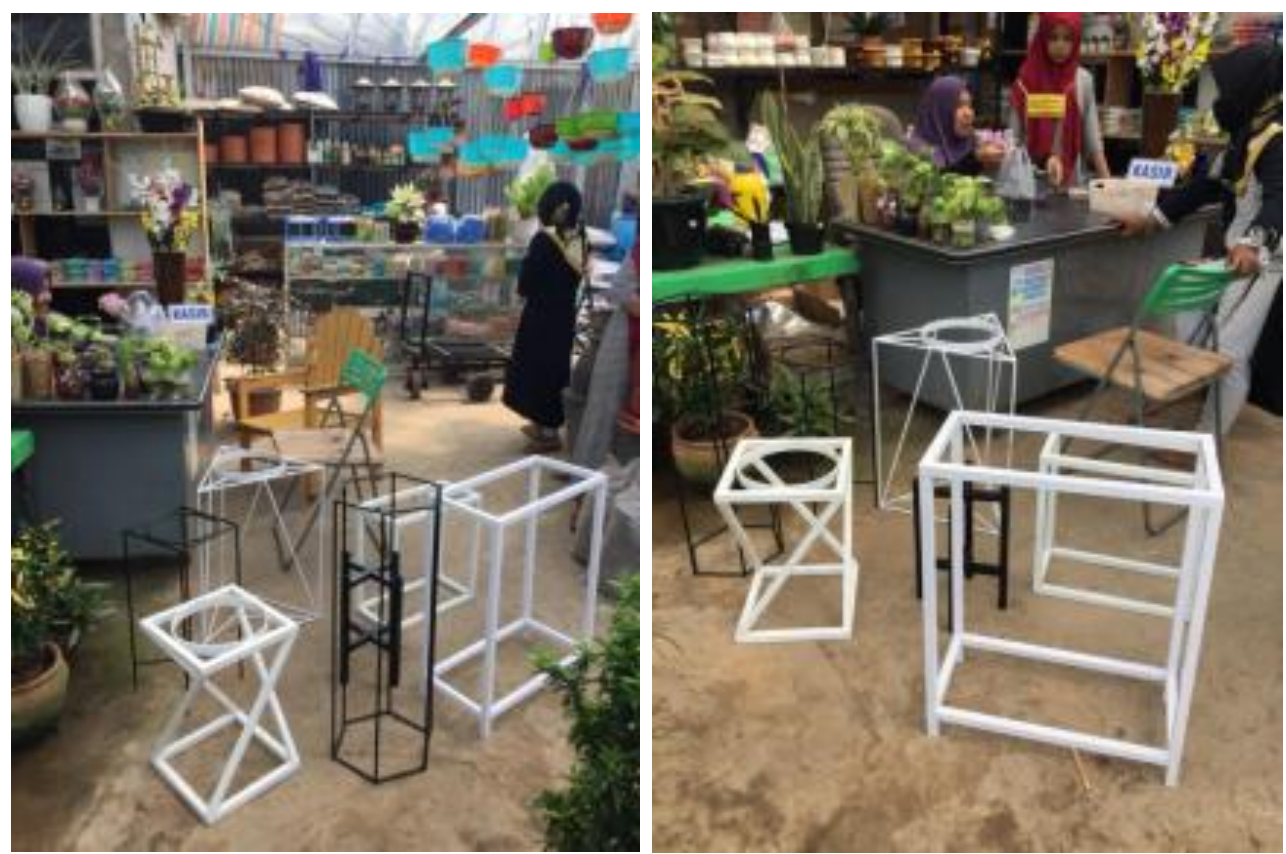

Gambar 3. Hasil produk workshop pembuatan pot geometris

\section{Workshop Merangkai Terarium}

Workshop kedua yaitu merangkai terarium dilaksanakan di Warung Upnormal Makassar, narasumber workshop adalah Tim Macora Garde. Peserta Kegiatan terdiri dari kelompok perempuan penjual tanaman hias Maccini Sombala. Wadah yang digunakan membuat terarium pada workshop ini adalah wadah berbentuk geometri dengan rangka besi kuningan dan permukaan kacadan wadah vas kaca Fish Ball. Adapun jenis terarium yang dibuat adalah terarium kering 
bertema natural. Rangkaian Kegiatan ini terdiri dari pengenalan terarium meliputi sejarah dan pemanfaatannya saat ini, praktik pemilihan tanaman untuk terarium meliputi jenis, ukuran dan cara tumbuhnya, beberapa contoh terarium, penyiapan alat dan bahan, praktik pembuatan terarium yang diawali dengan penentuan tema, pembuatan layer, pemasukan tanaman ke dalam wadah, penataan tanaman dengan penambahan elemen, mendekor terairum, penyemprotan dengan sprayer, pemajangan terarium, dan teknik perawatan terarium (Gambar 4).

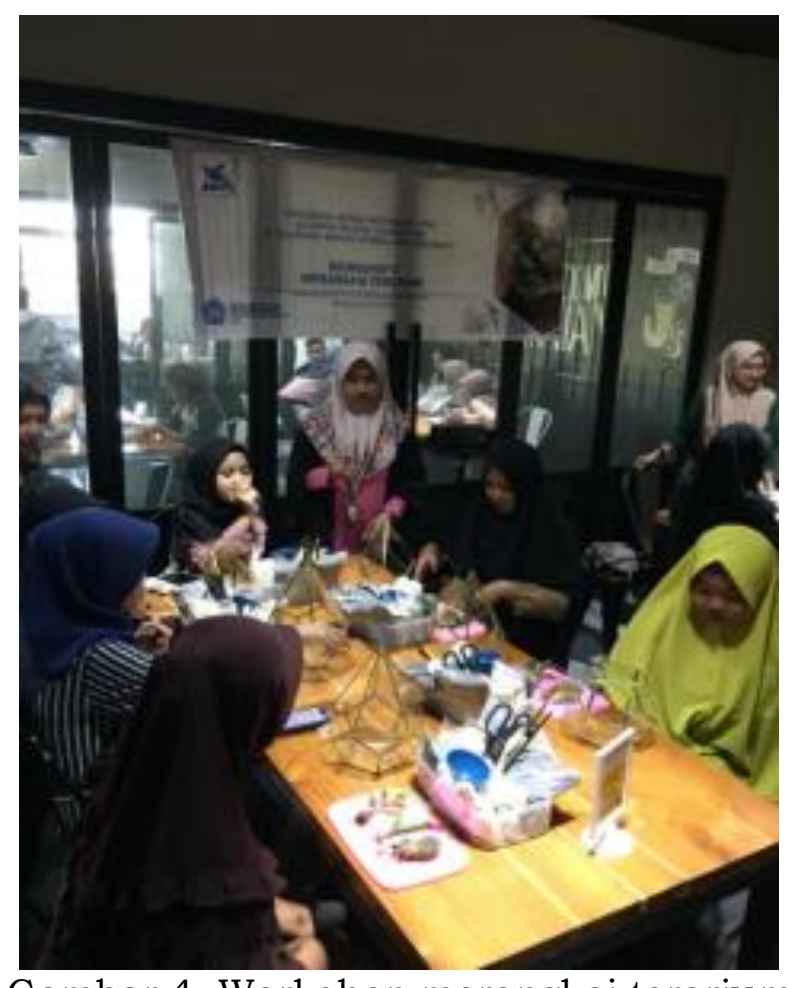

Gambar 4. Workshop merangkai terarium

\section{E. Workshop Pembuatan Website dan Pemasaran Digital serta Pembuatan Video Digital POTOMETRIUM}

Workshop ketiga adalah pembuatan dan penggunaan website toko online dengan narasumber dari Tim Web dan Application Programmer Perdana Angkasa Mandiri. Adapun Output dari workshop ini adalah peserta memahami penggunaan website sehingga nantinya produk tanaman hias yang dijual dapat diperoleh via online. Adapun tahapan yang diajarkan kepada peserta adalah cara berbelanja online, mensetting konfigurasi, menambahkan kategori, dan menambahkan barang. Selain itu peserta juga diajarkan trik pemasaran agar dapat menarik banyak pengunjung online. Website tanaman hias online ini dapat diakses melalui situs toko www.potometrium.com. Workshop selanjutnya adalah Workshop pemasaran digital, yang mengajarkan peserta mengenal teknik Marketing melalui media sosial, pentingnya menggunakan media sosial, konsep dasar dari media sosial dan menghasilkan prospek pemasaran dari media sosial. Setelah seluruh rangkaian workshop selesai dilaksanakan, maka dilakukan pembuatan video tutorial POTOMETRIUM yang terdiri dari penyiapan perangkat digital, pembuatan video pelaksanaan workshop POTOMETRIUM, proses mengedit video, dan mengunggah video di laman youtube.

\section{F. Display Produk POTOMETRIUM dan Monitoring Evaluasi Pelaksanaan Kegiatan}

Tahap akhir dari kegiatan ini adalah display produk POTOMETRIUM dan melakukan monitoring dan evaluasi pasca rangkaian workshop selesai dilaksanakan. Kegiatan monitoring berupa uji petik aplikasi keterampilan anggota 
kelompok pada produk, dan kemampuan mitra dalam pengaplikasian website. Selain kunjungan lapangan, monitoring dilakukan secara daring online pada website yang telah dibuat. Selain itu kontrolling juga dilakukan terhadap wadah dan produk tanaman hias yang didisplay dan minat pembeli terhadap produk POTOMETRIUM. Pada saat pemantauan dilakukan kembali upaya upaya yang bisa menumbuhkan kreatifitas dan keahlian kelompok mitra untuk mengembangkan usahanya secara jangka panjang dan monev realisasi perencanaan jangka panjang untuk peningkatan produksi dan kapasitas mitra terutama dalam pengembangan pemasaran dan produksi POTOMETRIUM kedepannya.

\section{H. Keberhasilan Kegiatan}

Kebermanfaatan dari kegiatan PPM POTOMETRIUM terlihat pada antusiasme peserta dalam mengikuti rangkaian kegiatan workshop dan desain produk yang dibuat oleh peserta workshop berupa produk pot geometris, terarium dan adanya website pihak mitra yang lebih memudahkan melalukan pemasaran online.

Pasca workshop selesai dilaksanakan pihak mitra sudah mulai merangkai terarium ke dalam wadah sederhana, terampil dalam pemilihan wadah dan merangkai kaktus maupun sukulen ke dalam mini terarium yang bernilai estetika (Gambar 5) dibanding sebelum mengikuti kegiatan workshop (Gambar 6 dan 7). Produk mini terarium tersebut saat ini sudah mulai didisplay dan dipasarkan pihak mitra di salah satu stan penjualan tanaman hias yang ada di Mall Panakkukang Makassar. Selain itu, keberhasilan kegiatan juga tampak pada produk POTOMETRIUM dan produk tanaman hias lainnya juga telah tersedia online pada website yang telah dibuat.
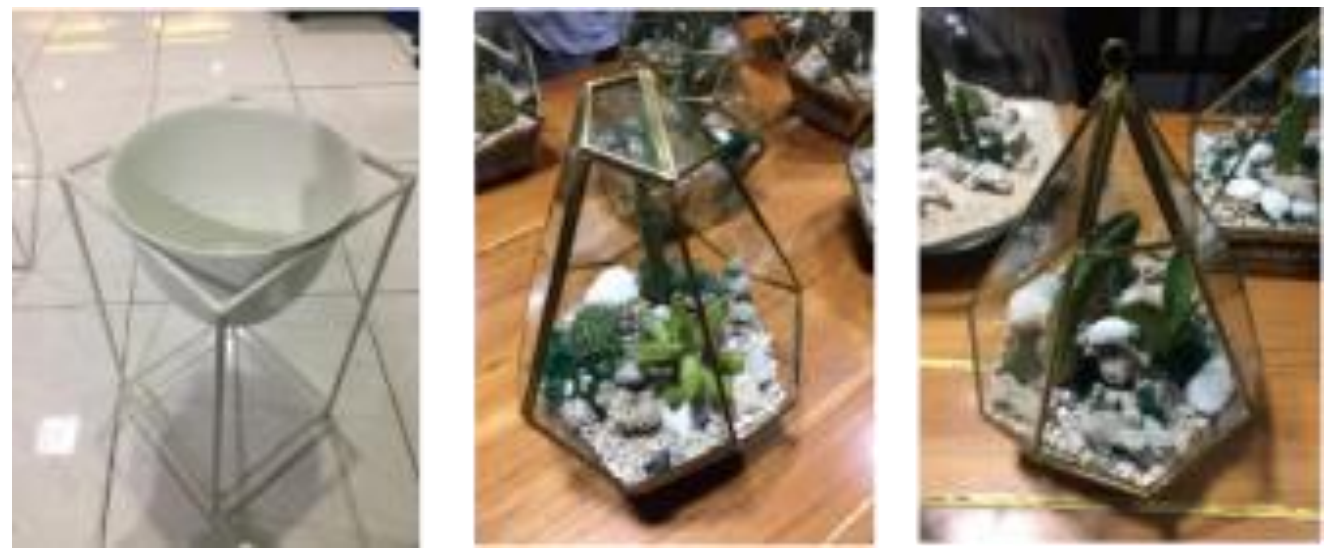

Gambar 5. Produk Workshop

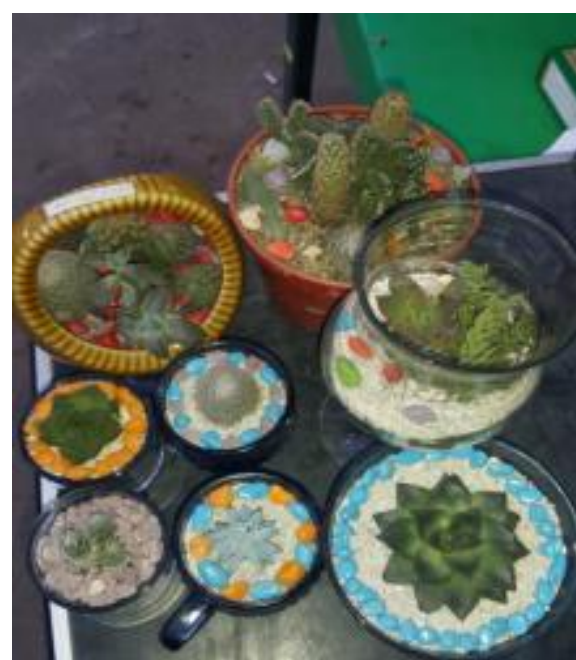

Gambar 6. Produk Tanaman Hias Sebelum Pelaksanaan Workshop POTOMETRIUM 

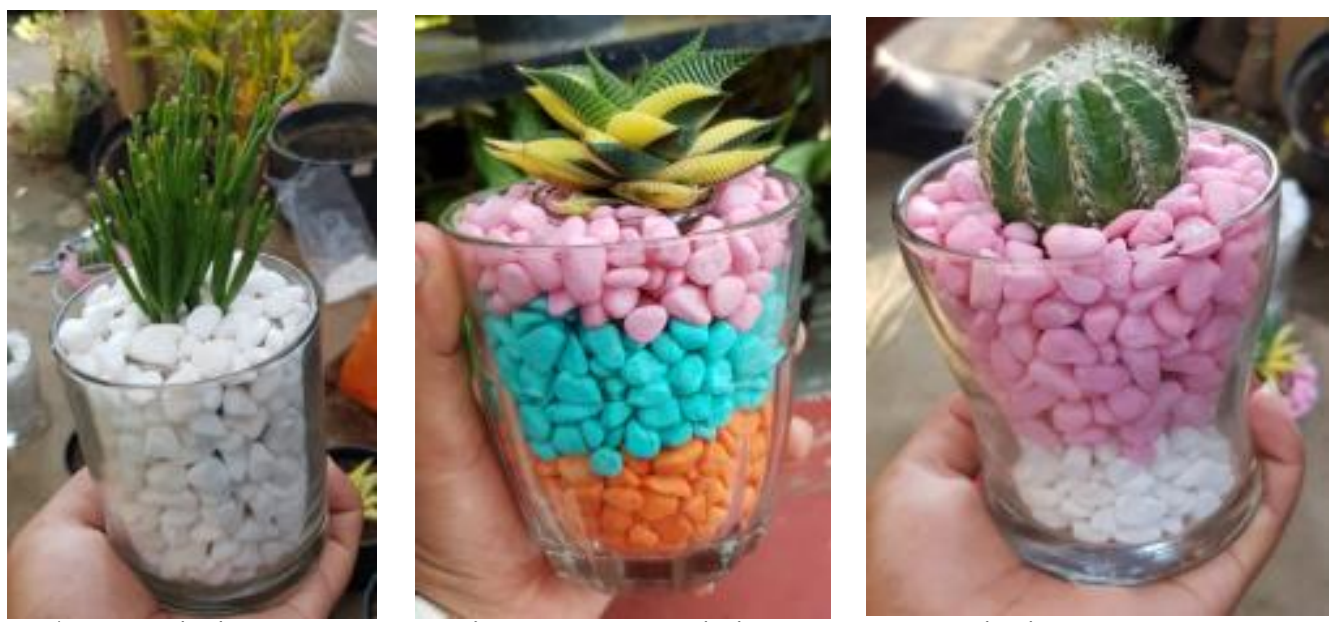

Gambar 7. Produk Tanaman Hias Pasca Pelaksanaan Workshop POTOMETRIUM

\section{Kesimpulan}

Kegiatan PPM POTOMETRIUM telah memberi dampak dalam berkembangnya keterampilan dan pengetahuan Kelompok Penjual Tanaman Hias dalam membuat pot geometris dan budidaya tanaman berupa merangkai terarium secara lebih menarik dan bernilai estetika tinggi. Produk terarium tersebut saat ini telah dipasarkan pada salah satu stan usaha yang ada di Mall Panakkukang Kota Makassar. Selain itu, sistem penjualan produk secara online juga dilakukan melalui website POTOMETRIUM sehingga memberikan peluang untuk menjangkau pasar yang lebih luas dan berimplikasi dalam peningkatan pendapatan Kelompok Penjual Tanaman Hias.

\section{Ucapan Terima Kasih}

Tim pengabdian mengucapkan terima kasih kepada Direktorat Riset dan Pengabdian Masyarakat (DRPM) Direktorat Jenderal Penguatan Riset dan Pengembangan Kementrian Riset, Teknologi, dan Pendidikan Tinggi (RISTEKDIKTI) Republik Indonesia atas bantuan pendanaan sehingga pengabdian masyarakat ini dapat terlaksana, juga kepada LP3M Universitas Muhammadiyah Makassar serta pihak mitra Kelompok Penjual Tanaman Hias Maccini Sombala.

\section{Referensi}

Anik, S.W., \& Ikmah. (2018). Pengembangan Strategi E-Marketing UMKM Klaten Utara. Seminar Hasil Pengabdian Masyarakat 2018. Universitas AMIKOM Yogyakarta.

Charina, A., Kusumo, R.A.B., \& Deliana, Y. (2012). Terrarium Sebagai Solusi Cara Bercocok Tanam Hemat Air, Lahan, Serta Pengurangan Polutan Pabrik di Desa Nasol dan Sindangsari Kecamatan Cikoneng Kabupaten Ciamis. Jurnal Aplikasi Ipteks Untuk Masyarakat, 1(1): 1-5.

Dewi, P.S., \& Widiyawati, I. (2019). Pengenalan Teknologi Budidaya Tanaman Obat sebagai Upaya Pemanfaatan Lahan Pekarangan di Kelurahan Pabuwaran Purwokerto, Jawa Tengah. Jurnal Panrita Abdi, 3(2): 105-113.

Utami, H.N., \& Firdaus, I.F. (2018). Pengaruh Bauran Pemasaran terhadap Perilaku Online Shopping; Perspektif Pemasaran Agribisnis. Jurnal Ecodemica, 2(1): 126-146.

Penulis:

Citra Amalia Amal, Program Studi Arsitektur, Fakultas Teknik, Universitas Muhammadiyah, Makassar. E-mail: citraamaliaamal@unismuh.ac.id 
Andi Annisa Amalia, Program Studi Arsitektur, Fakultas Teknik, Universitas Muhammadiyah, Makassar. E-mail: annisa@unismuh.ac.id

Sri Andayaningsih, Program Studi Manajemen, Fakultas Ekonomi dan Bisnis, Universitas Muhammadiyah, Makassar. E-mail: s.andayaningsih@yahoo.co.id

Bagaimana men-sitasi artikel ini:

Amal, C.A., Amalia, A.A., \& Andayaningsih, S. (2019). POTOMETRIUM (Pot Tanaman Geometris dan Terarium) serta Pemasaran Digital bagi Kelompok Penjual Tanaman Hias di Kelurahan Maccini Sombala Kota Makassar. Jurnal Panrita Abdi, 4(1), 110-118. 